\title{
PENEGAKAN HUKUM TERHADAP GUEST HOUSE DAN VILLA TANPA IZIN DI KABUPATEN BADUNG
}

\author{
Cinta Saraswati, I Made Arjaya, Diah Gayatri Sudibya \\ Fakultas Hukum Universitas Warmadewa, Denpasar-Bali, Indonesia \\ Cintasaraswati18@gmail.com, imd.arjaya@gmail.com, diahgayatrisudibya@gmail.com
}

\begin{abstract}
Abstrak
Pariwisata menjadi salah satu sumber pendapatan asli daerah dan investasi di dalamnya merupakan faktor produksi berpotensi vital dalam bisnis produksi jasa di bidang tersebut. Sebagai pendukung akomodasi pariwisata di daerah kawasan wisata Kabupaten Badung, diperlukanlah Guest House (rumah kos/kontrakan) dan Villa sebagai penunjang. Khususnya di Kabupaten Badung terutama di kawasan Canggu banyak rumah-rumah dijadikan Guest House bagi para tamu yang ingin menginap di Bali. Penelitian ini bertujuan untuk mengetahui pengawasan terhadap Guest House dan Villa di Kabupaten Badung, dan untuk mengetahui penerapan sanksi terhadap guest house dan villa yang melanggar perizinan di Kabupaten Badung. Metode dalam penelitian ini adalah tipe penelitian hukum normatif yang dilakukan dengan metode pencatatan dan pengkajian berdasarkan bahan hukum. Dalam penelitian ini, mengkaji dan mengumpulkan informasi melalui buku ilmu hukum tanpa melenceng dari hukum positif demi merangkai sebuah kesimpulan. Hasil penelitian menujukkan bahwa pengawasan terhadap Guest House dan Villa di Kabupaten Badung diberikan kewenangan oleh Peraturan Daerah melalui Satuan Polisi Pamong Praja yang ditugaskan untuk memantau setiap bangunan yang tidak memiliki izin di kawasan Kabupaten Badung khususnya di wilayah Canggu. Kemudia, sanksi terhadap pelanggar berupa peringatan sebanyak 3 kali, bila membangkang pemilik Villa dikenakan sanksi pembongkaran paksa oleh petugas.
\end{abstract}

Kata Kunci:; Izin; Guest House; Pengawasan; Villa

\begin{abstract}
Tourism is a source of local revenue and its investment is a potentially vital production factor in the service production business in this field. To support tourism accommodation in the tourist area of Badung Regency, guest houses (boarding houses/rented houses) and villas are needed as support. Especially in Badung Regency, in the Canggu area, many houses are used as guest houses for guests who want to stay in Bali. This study aims to determine the supervision of Guest Houses and Villas in Badung Regency, and to determine the application of sanctions against guest houses and villas that violate permits in Badung Regency. The method in this research is a type of normative legal research which is carried out with the method of recording and reviewing based on legal materials. In this study, studying and gathering information through legal science books without deviating from positive law in order to form a conclusion. The research results show that the supervision of Guest Houses and Villas in Badung Regency is given the authority by the Regional Regulation through the Civil Service Police Unit which is assigned to monitor every building that does not have a permit in the Badung Regency area, especially in the Canggu area. Then, sanctions against violators are in the form of warnings 3 times, if they do not disobey the villa owner, they will be subject to forced demolition by officers.
\end{abstract}

Keywords: Permission; Guest House; Supervision; Villa

\section{PENDAHULUAN}

Pariwisata telah menjadi salah satu sumber pendapatan asli daerah dan investasi merupakan faktor produksi yang berpotensi vital dalam bisnis produksi jasa (Nurhayati, 2016; Pleanggra \& Yusuf A.G, 2012). Kegiatan pariwisata yang ada di kawasan Kabupaten Badung saat ini semakin berkembang, banyak wisatawan asing yang berkunjung, menginap dan melakukan aktivitas di kawasan daya tarik wisata di Kabupaten Badung. Guna menunjang kegiatan tersebut lokasi kegiatan akomodasi pariwisata yang ada di Kabupaten Badung semakin menjamur yaitu adanya villa dan Guest House sebagai akomodasi pariwisata. Sebagai pendukung akomodasi pariwisata yang tinggal di daerah kawasan wisata Kabupaten Badung, diperlukanlah Guest House (rumah kos/kontrakan) dan Villa sebagai penunjang. Khususnya di Kabupaten Badung terutama di kawasan Canggu banyak rumah- 
rumah dijadikan Guest House bagi para tamu yang ingin menginap di bali. Karena saking maraknya wisatawan yang menginginkan tempat bermalam dengan biaya yang murah, maka rumah dijadikan tempatnya yang dikenal dengan Guest House yang tidak memiliki izin.

Villa mengacu pada Peraturan Bupati Badung Nomor 5 tahun 2016 tentang Standarisasi Usaha Villa, hal tersebut disebabkan seiring pertumbuhan dan perkembangan penduduk yang pesat memberi dorongan terhadap penggunaan ruang, dan rumah-rumah sebagai Guest House dan villa, serta pola pembangunan yang dilakukan oleh masyarakat. Perkembangan pembangunan Guest House dan Villa di Kabupaten Badung ini semakin meningkat, Salah satunya sebagai sarana penunjang akomodasi pariwisata rumah dipergunakan sebagai Guest House dan villa. Banyaknya Guest House dan Villa yang tidak memiliki izin mendirikan bangunan, sehingga terjadinya pelanggaran hukum di bidang perizinan (Atmosudirjo, 1983; Ernawati et al., 2019; Sukradana et al., 2018).

Eksekusi penegakan Perda oleh Satpol PP Provinsi Bali kemarin didampingi PPS Provinsi Bali, Satpol PP Kabupaten Badung serta didukung satuan keamanan dari Polsek Kuta Utara dan Koramil. Upaya penegakan Perda yang dilakukan diharapkan membuat sempadan pantai bersih dari bangunan liar. Tak hanya di kawasan Canggu, hal yang sama juga akan dilakukan bila di kawasan lain terjadi pelanggaran serupa. Penertiban dilakukan karena pemilik bangunan sudah kami berikan SP3, dan hari ini (kemarin) kami lakukan pembongkaran. Pemilik bangunan menyadari kesalahannya.

Berdasarkan uraian di atas, maka penelitian ini bertujuan untuk mengetahui pengawasan terhadap Guest House dan Villa di Kabupaten Badung, dan untuk mengetahui penerapan sanksi terhadap guest house dan villa yang melanggar perizinan di Kabupaten Badung.

\section{METODE PENELITIAN}

Pencarian informasi secara normatif berpatokan pada peraturan pemerintah yang berfokus pada Guest House dan Villa sebagai objeknya dan analisis dalam Informasi yang didapat secara konseptual berkaitan dengan penulisan ini. Penelitian hukum normatif adalah hukum kepustakaan yang mengacu pada norma hukum yang terdapat dalam peraturan Perundang-undangan (Waluyo, 2002). Penelitian ini dilakukan dengan tidak menyimpang dari hukum positif dan melalui permasalahan yang dipaparkan di atas. Pendekatan perundangan-undangan adalah suatu penelitian yang berpatokan pada undang - undang sebagai dasar penenelitian. Pendekatan kasus dilakukan guna melihat, mencatat dan memahami permasalahan yang diangkat dalam penelitian ini dengan tidak keluar dari zona hukum positif. Penelitian kasus ini menggunakan metode normatif dan kualitatif dimana dalam pengerjaannya penulis menelaah isu hukum dengan didasari peraturan - peraturan hukum Pidana yang berlaku di Indonesia (Ahmad, 2008).

\section{HASIL DAN PEMBAHASAN}

\section{Pengawasan terhadap Guest House dan Villa di Kabupaten Badung}

Untuk penerbitan IMB Guest House dan Villa di Kabupaten Badung harus sesuai dengan mekanisme pelayanan perizinan yaitu pemohon datang ke tempat (counter) informasi untuk mengambil formulir permohonan dan persyaratan dan pemohon melakukan pengecekan gambar ke tempat informasi tentang persyaratan tata bangunan dan lingkungan yang diberlakukan oleh Pemerintah Kabupaten Badung. (Advice Planning) untuk disetujui gambarnya. Apabila permohonan lengkap dan benar maka permohonan diterima dan pemohon akan diberikan tanda terima oleh CSO (customer service officer), apabila berkas permohonan tidak lengkap dan benar maka akan ditolak dengan memberikan konsultasi beserta alasan-alasan yang menjadi penolakannya.

Pemohon yang telah diterima akan di lakukan verifikasi ke lapangan oleh petugas tim lapangan pelayanan perizinan dan hasil verifikasi akan dituangkan ke dalam (BAP), Berita Acara Pemeriksaan Lapangan oleh masing - masing anggota tim dan diserahkan ke Kasubid Pelayanan Perizinan pada bidang pelayanan perizinan pemerintahan dan pembangunan, Untuk merekomendasi berkas apakah dapat diproses atau ditolak oleh kasubid pelayanan perizinan pada bidang pelayanan pemerintahan dan pembangunan ada dua tahap yaitu: ditolak dan diproses. Ketika ditolak, maka harus membuat surat penolakan oleh pihak yang melakukan verifikasi dan diserahkan langsung ke kepala bidang pelayanan perizinan pemerintahan dan pembangunan untuk di paraf dan diserahkan ke sekretaris, dari sekretaris diserahkan ke kepala badan pemerintahan dan pembangunan untuk ditandatangani surat penolakan dan berkas dibawa ke bagian informasi untuk diserahkan kepada pemohon. Kemudian, diproses apabila BAP (berita acara pemeriksaan lapangan) dengan verifikasi di lapangan sesuai maka 
permohonan diproses akan dilanjutkan ke kasubid verifikasi dan penetapan untuk pencetakan sertifikasi Izin (SKRD) surat ketetapan retribusi daerah dan, sertifikat diparaf dan ditandatangani oleh ke kasubid pelayanan perizinan pemerintahan dan pembangunan dan diserahkan ke bagian sekretaris sertifikat SKRD untuk ditandatangani, dan diserahkan langsung ke kepala badan perijinan untuk ditandatangani sertifikat Izin Mendirikan Bangunan (IMB). Dokumen kemudain dibawa ke penjilidan, setelah dijilid diletakkan di loket pengambilan, dan pemohon melakukan transaksi pembayaran di BPD (Bank Pembangunan Daerah) Bali serta dilakukan pengarsipan.

Mengenai jangka waktu penyelesaian IMB adalah 10 Hari jam kerja setelah berkas permohonan dinyatakan lengkap dan benar, bahkan terkadang waktu penyelesaian ini secara teknis atau pada prakteknya tidak dapat dipastikan karena sering terjadi penundaan waktu atau bahkan penyelesaian untuk satu IMB memakan waktu lebih dari satu bulan lamanya, jadi mengenai jangka waktu penyelesaian IMB adalah relatif hal ini tergantung atas permasalahan yang timbul pada IMB tersebut ataupun hal lainnya. IMB baru dapat diterbitkan setelah pengecekan lapangan selesai dan setelah permohonan tersebut memenuhi persyaratan baik syarat administrative maupun syarat teknis bangunan atau tidak terdapat kendala lainnya sehubungan dengan penerbitan IMB tersebut. Pembangunan Kabupaten Badung dikategorikan sebagai wujud nyata proses Pembangunan yang sangat pesat, hal ini dapat dilihat dari permohonan masyarakat untuk mengajukan IMB terus meningkat. Kegiatan mendirikan Bangunan hunian (rumah) tempat tinggal, gedung dan pembangunan bangunan lainnya di Kabupaten Badung telah berkembang dengan cukup pesat, Kabupaten Badung sebagai Kota Budaya berwawasan lingkungan, dipandang perlu mengatur dan mengendalikan berdirinya bangunan serta menjaga pelestarian, bangun - bangunan yang mempunyai nilai sejarah, sehingga untuk setiap mendirikan, merubah ataupun merobohkan harus memenuhi persyaratan sesuai peraturan perundang - undangan yang berlaku, sehingga diperlukannya peraturan Kabupaten Badung tentang Izin bangunan.

Setiap pembangunan yang akan dilakukan khususnya pembangunan dalam bentuk hunian ataupun bangunan lainnya seperti ruko haruslah mengantongi IMB terlebih dahulu dan dilengkapi dengan perizinan lainnya yang diperlukan, Ijin IMB ini tidaklah keluar dengan sendirinya atau keluar begitu saja, ada proses - proses penyaringan yang harus diikuti oleh tiap pemohon dan kelengkapan persyaratan lainnya yang terkait dengan permohonan IMB tersebut, hal ini penting sebagai pengaturan agar tidak terjadi dampak - dampak negatif yang dimungkinkan timbul karena perkembangan tersebut, khususnya dampak terhadap lingkungan sekitar. Kewenangan merupakan bagian dari penegakan hukum dalam pemberian izin Guest House dan Villa Dalam sistem penegakan hukum. Soekanto (1983) mengemukakan bahwa inti dan arti penegakan hukum, secara konsepsional terletak pada kegiatan menyerasikan hubungan nilai-nilai yang terjabarkan di dalam kaidah- kaidah yang mantap dan mengejawantah dan sikap tindak sebagai rangkaian penjabaran nilai tahap akhir, untuk menciptakan, memelihara, dan mempertahankan kedamaian pergaulan hidup.

Pelaksanaan kewenangan pemerintah berdasarkan Penyelenggaraan pemerintahan di daerah dilaksanakan asas - asas Pemerintah daerah. Asas - asas tersebut antara lain asas desentralisasi, asas dekonsentrasi, dan asas tugas pembantuan. Daerah provinsi, daerah, Kabupaten dan daerah Kota. Daerah Otonom ini berwenang mengatur dan mengurus kepentingan masyarakat setempat menurut caranya sendiri berdasarkan aspirasi masyarakat. Dengan demikian maka kebijakan - kebijakan yang dikeluarkan oleh pemerintah Daerah selalu didukung oleh masyarakat setempat. Berdasarkan asas umum pemerintahan ini, yang menjadi urusan pemerintahan daerah salah satunya adalah dalam bidang legislasi, yakni atas prakarsa sendiri membuat peraturan daerah dan peraturan Kepala daerah yang meliputi Perda provinsi dan kabupaten / Kota (Ridwan, 2008).

Setiap bangunan yang ada di Kabupaten Badung sudah seharusnya memiliki Izin Mendirikan Bangunan (IMB). Perijinan ini dibentuk oleh pemerintah Kabupaten badung Guna menjaga ketertiban bangunan yang ada di Kabupaten badung. Kurangnya sosialisasi yang dilakukan oleh Pemerintah Kabupaten badung kepada masyarakat mengenai Izin Membangun ini, menyebabkan banyak terjadi pelanggaran yang ditemukan oleh petugas ketika melakukan pengecekan terhadap bangunan tersebut di lapangan. Banyaknya terjadi pelanggaran diakibatkan beberapa alasan diantaranya karena kesadaran yang rendah dari masyarakat, karena lokasi atau lahan yang tidak memadai karena adanya aturan jarak sempadan bangunan yang dianggap dapat memberatkan dan memakan lahan yang banyak, rendahnya kesadaran dan rasa takut terkena sanksi hukum, prosedur permohonan yang cukup 
merepotkan dan terkesan sulit serta tidak sesuai dengan alur bagan yang digambarkan, pelayanan yang tidak memuaskan.

\section{Penerapan Sanksi terhadap Guest House dan Villa yang Melanggar Perizinan di Kabupaten Badung}

Banyaknya jumlah pelanggaran bangunan yang terjadi di Kabupaten badung dikarenakan oleh kurangnya kesadaran masyarakat untuk mengurus ijin mendirikan bangunan ataupun juga karena kurangnya pengetahuan masyarakat tentang prosedur pendirian bangunan di Kabupaten badung. Kadang kala ada juga masyarakat yang nakal dalam hal pendirian bangunan seperti ijin mendirikan bangunannya sudah ada namun bangunan yang dibangunnya tidak sesuai dengan gambar sket bangunan yang didaftarkan di Dinas Perizinan Kabupaten badung. Selain itu juga karena masih kurangnya kinerja aparat penegak hukum dalam menerapkan peraturan daerah, yang pada saat ini petugas lapangan yang mengawasi pendirian bangunan yang ada di Kabupaten badung masih minim. Untuk menyikapi kendala - kendala yang dihadapi oleh pemerintah Kabupaten badung dalam penerapan izin mendirikan bangunan, maka pemerintah Kabupaten badung melakukan beberapa upaya untuk menanggulangi kendala semisal ketentuan menurut Soekanto (2004), yakni:

1. Bangunan yang sudah disetujui persetujuan prinsip membangunnya agar dalam melakukan pembangunan di lapangan agar diawasi oleh petugas terkait sehingga tidak terjadi pelanggaranpelanggaran dalam membangun.

2. Masyarakat harus mentaati aturan yang sudah diberikan oleh petugas.

3. Terhadap bangunan yang sudah berdiri, petugas meminta agar pemohon melampiri surat keterangan yang menyatakan bahwa bangunan sudah berdiri.

4. Melakukan sosialisasi terhadap masyarakat sekitar tentang pentingnya memiliki izin.

5. Kepala desa/lurah dan bendesa adat wajib memonitor, mengawasi dan melaporkan setiap pembangunan di wilayahnya apakah telah sesuai dengan peraturan yang berlaku.

Sanksi yang diterapkan dalam persetujuan Prinsip Membangun adalah sanksi administrasi yang berupa pemanggilan kepada pemohon terkait dengan izin yang dimohon oleh pemohon yang bersangkutan. Pemanggilan ini dilakukan oleh instansi terkait sebanyak tiga kali. Apabila pemohon tidak menanggapi maka pemohon dikenakan sanksi berupa sanksi teknis. Sanksi teknis yang biasanya dilakukan oleh pemerintah dalam hal ini yang berwenang adalah Dinas Tramtib dan Satpol PP Kabupaten badung adalah berupa pembongkaran bangunan yang dilakukan secara paksa, dalam Hukum Administrasi, sanksi teknis dikaitkan dengan paksaan pemerintah dan pengenaan uang paksa oleh pemerintah. Dengan dikeluarkannya Perda Izin Mendirikan bangunan setiap pelanggaran akan ditindak diberikan sanksi sesuai dengan tingkat kesalahannya. Prosedur penerapan sanksi terhadap pelanggaran Izin Mendirikan Bangunan Guest House dan Villa melalui Tindak pidana ringan dengan satu orang hakim dan Panitera Pengganti, sedangkan sebagai penuntut adalah Polisi Pamong Praja sebagai pengawal Perda Badung. Pelaksanaan tindak pidana ringan tidak selalu dilakukan melalui di Pengadilan Negeri Denpasar, tetapi juga bisa dilakukan di Banjar maupun di balai desa apabila pelaku tindak pidana ringan banyak, dalam Penerapan sanksi terhadap Guest House dan Villa tidak memiliki Izin Mendirikan Bangunan.

\section{SIMPULAN DAN SARAN}

1. Simpulan

Berdasarkan uraian di atas, dapat disimpulkan bahwa pengawasan terhadap guest house dan villa di Kabupaten Badung dilakukan diberikan kewenangan oleh Peraturan Daerah melalui Satpol PP, dimana setia bangunan yang tidak memiliki izin di kawasan Kabupaten Badung khususnya di Wilayah Canggu, karena setiap Bangunan sudah seharusnya memiliki Izin mendirikan Bangunan (IMB). Di dalam mengurus izin mendirikan bangunan masyarakat Kabupaten badung dapat mengurusnya pada badan pelayanan perizinan terpadu satu pintu dan penanaman modal Kabupaten Badung, dalam bentuk pengawasan kurangnya kesadaran dari masyarakat tentang prosedur permohonan dan jangka waktu penyelesaian IMB yang tidak sesuai dengan ketentuan, kesadaran masyarakat yang rendah, Longgarnya pemberian izin oleh pemerintah, adanya toleransi atas pelanggaran, dan kurang mengertinya masyarakat atas pemahaman pentingnya IMB. Kemudian, penerapan sanksi terhadap guest house dan villa yang melanggar perizinan di Kabupaten Badung, apabila Pelanggaran Izin Mendirikan Bangunan ( IMB ) akan dikenai sanksi sesuai dengan bentuk pelanggarannya dengan 
memberikan pembinaan terlebih dahulu sebagai somasi guna melakukan pengurusan Izin mendirikan bangunan, apabila peringatan yang diberikan oleh Sat.Pol PP sebanyak 3 kali, maka pemilik Villa akan dikenakan sanksi pembongkaran paksa oleh petugas Sat.Pol PP atas rekomendasi dari Bupati Kepala Daerah Kabupaten Badung.

\section{Saran}

Beberapa saran yang hendak disampaikan berdasarkan hasil penelitian di atas, yaitu kiranya seluruh masyarakat dari Indonesia khususnya di pulau Bali ketika hendak mendirikan bangunan Guest House dan villa haruslah memiliki izin bangunan agar penataan ruang wilayah Kabupaten Badung tertib. Disarankan juga kepada para aparat penegakan peraturan daerah ini, kiranya memberikan sanksi yang tegas terhadap para pelanggar bangunan ini, guna memberikan efek jera kepada mereka yang melanggar. Selain itu juga perlunya tambahan personil yang mengawasi bangunan - bangunan yang berdiri di Kabupaten badung.

\section{DAFTAR PUSTAKA}

Ahmad, B. (2008). Metode Penelitian Hukum. Pustaka Setia.

Atmosudirjo, P. (1983). Hukum Administrasi Negara. Ghalia Indonesia.

Ernawati, N. M., Basi Arjana, I. W., \& Jendra, W. (2019). Jasa Penginapan Pendukung Geowisata di Batur Bali. Jurnal Bisnis Dan Kewirausahaan, 15(1), 13-21.

Nurhayati. (2016). Analisis Investasi Sektor Pariwisata oleh Pemerintah Daerah Kota Batam Tahun 2014. Jurnal Dimensi, 5(2), 1-22.

Pleanggra, F., \& Yusuf A.G, E. (2012). Wisatawan Dan Pendapatan Perkapita Terhadap Kabupaten / Kota Di Jawa Tengah. Universitas Diponegoro, 1(1), 1-8.

Ridwan, H. (2008). Hukum Administrasi Negara. PT Raja Grafindo Persada.

Soekanto, S. (1983). Penegak Hukum. Binacipta.

Soekanto, S. (2004). Faktor-Faktor Yang Mempengaruhi Penegakan Hukum (Cetakan Ke). Raja Grafindo Persada.

Sukradana, Ariana, I. N. J., \& Sari, N. P. R. (2018). Dampak keberadaan villa bagi masyarakat di Banjar Canggu Kuta Bali. Jurnal Kepariwisataan Dan Hospitalitas, 2(1), 42-60.

Waluyo, B. (2002). Penelitian Hukum Praktek. Sinar Grafika. 